\title{
Complete genome sequence of the sulfur-oxidizing chemolithoautotrophic Sulfurovum lithotrophicum $42 \mathrm{BKT}^{\mathrm{T}}$
}

Wooyoung Jeon ${ }^{1,2}$, Lia Priscilla ${ }^{1,3}$, Gyuyeon Park ${ }^{1,2}$, Heeseok Lee ${ }^{1,2}$, Narae Lee ${ }^{4}$, Dongyup Lee ${ }^{4}$, Hyuksung Kwon ${ }^{5}$, Iksung Ahn ${ }^{5}$, Changha Lee ${ }^{5}$, Hongweon Lee ${ }^{1,2}$ and Jungoh Ahn ${ }^{1,2^{*}}$ (i)

\begin{abstract}
A sulfur-oxidizing chemolithoautotrophic bacterium, Sulfurovum lithotrophicum $42 \mathrm{BKT}{ }^{\top}$, isolated from hydrothermal sediments in Okinawa, Japan, has been used industrially for $\mathrm{CO}_{2}$ bio-mitigation owing to its ability to convert $\mathrm{CO}_{2}$ into $\mathrm{C}_{5} \mathrm{H}_{8} \mathrm{NO}_{4}^{-}$at a high rate of specific mitigation $\left(0.42 \mathrm{~g} \mathrm{CO}_{2} / \mathrm{cell} / \mathrm{h}\right)$. The genome of S. lithotrophicum $42 \mathrm{BKT}^{\top}$ comprised of a single chromosome of 2217,891 bp with 2217 genes, including 2146 protein-coding genes and 54 RNA genes. Here, we present its complete genome-sequence information, including information about the genes encoding enzymes involved in $\mathrm{CO}_{2}$ fixation and sulfur oxidation.
\end{abstract}

Keywords: Complete genome, Sulfur-oxidizing bacterium, Chemolithoautotroph, $\mathrm{CO}_{2}$ bio-mitigation, Sulfurovum lithotrophicum

\section{Introduction}

Epsilonproteobacteria are well-known chemolithoautotrophic bacteria found in deep-sea hydrothermal fields that play significant roles in sulfur, nitrogen, and hydrogen flux $[1,2]$.

Sulfurovum lithotrophicum $42 \mathrm{BKT}^{\mathrm{T}}$ is a sulfur-oxidizing member of Epsilonproteobacteria that was isolated from deep-sea hydrothermal sediments in Okinawa, Japan [3]. Strain $42 \mathrm{BKT}^{\mathrm{T}}$ is a Gram-negative, non-motile, and coccoid-to-short-rod-shaped bacterium that utilizes $\mathrm{CO}_{2}$ as a carbon source, $\mathrm{S}$ or $\mathrm{S}_{2} \mathrm{O}_{3}^{2-}$ as electron donors, and $\mathrm{O}_{2}$ and $\mathrm{NO}_{3}^{-}$as electron acceptors [3, 4]. Recent studies have focused on its potential industrial applications for $\mathrm{CO}_{2}$ bio-mitigation, reporting that this strain could convert $\mathrm{CO}_{2}$ into $\mathrm{C}_{5} \mathrm{H}_{8} \mathrm{NO}_{4}^{-}$at a high specific mitigation rate of $\sim 0.42 \mathrm{~g} \mathrm{CO}_{2} / \mathrm{cell} / \mathrm{h}[4]$.

The $\mathrm{CO}_{2}$-bio-mitigation ability of S. lithotrophicum can be improved and optimized through genetic engineering; however, the present lack of genetic knowledge of $S$.

\footnotetext{
*Correspondence: ahnjo@kribb.re.kr

'Biotechnology Process Engineering Center, KRIBB, 40 Yeongudanji-ro, Cheongju 363-883, South Korea

${ }^{2}$ Bioprocess Department, University of Science and Technology, 217

Gajeong-ro Yuseong-gu, Daejeon, South Korea

Full list of author information is available at the end of the article
}

lithotrophicum renders the genetic engineering of this strain difficult. Here, we presented a preliminary description and the general features of S. lithotrophicum $42 \mathrm{BKT}^{\mathrm{T}}$, along with its genome-sequence annotations and interactions with other Sulfurovum species. This information would be helpful for improving the use of chemolithoautotrophic bacteria, including Sulfurovum species, in industrial applications in $\mathrm{CO}_{2}$ bio-mitigation.

\section{Organism information \\ Classification and features}

A representative $16 \mathrm{~S}$ rRNA gene of $S$. lithotrophicum $42 \mathrm{BKT}^{\mathrm{T}}$ was compared with that of other species using NCBI BLAST [5]. Figure 1 shows the phylogenetic tree with S. lithotrophicum $42 \mathrm{BKT}^{\mathrm{T}}$, constructed based on the 16S rRNA sequence. This strain shared 99.1\% (1393/ $1406 \mathrm{bp})$ and $95.1 \%(1312 / 1379)$ sequence identity with the $16 \mathrm{~S}$ rRNA genes of Sulfurovum sp. NBC37-1 [6] and Sulfurovum aggregans Monchim $33^{\mathrm{T}}$, respectively.

S. lithotrophicum $42 \mathrm{BKT}^{\mathrm{T}}$ is a Gram-negative, nonmotile, coccoid-to-short-rod-shaped bacterium that is $0.5-1.2 \mu \mathrm{m}$ in length and $0.4-0.8 \mu \mathrm{m}$ in width (Fig. 2). The $42 \mathrm{BKT}^{\mathrm{T}}$ strain is a mesophilic, facultative anaerobe that requires sea salt to grow and can use $\mathrm{NH}_{4} \mathrm{Cl}$ as a nitrogen source. Normal growth occurs at a 


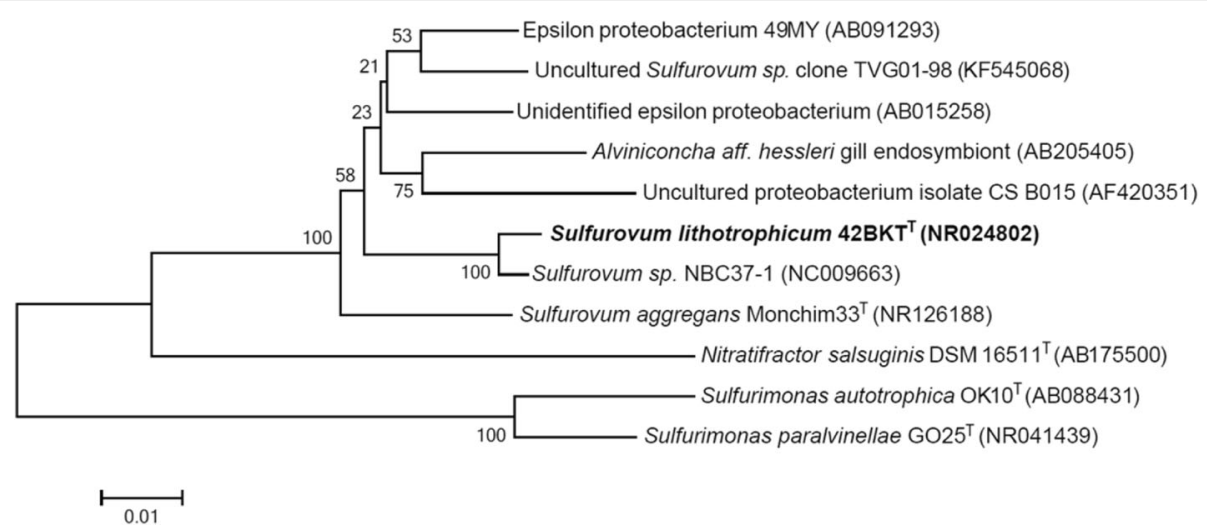

Fig. 1 Phylogenetic tree showing the relative position of Sulfurovum lithotrophicum 42BKT', based $16 \mathrm{~S}$ rRNA gene sequence. All sites were informative and free of gaps. Evolutionary history was inferred using the neighbor-joining method [35]. The tree was built using the maximum composite-likelihood method [36]. The percentage of replicate trees with the associated taxa clustered together in the bootstrap test (1000 replicates) is shown next to the corresponding branches [37]. Evolutionary analyses were conducted in MEGA6 [38]. Corresponding GenBank accession numbers are shown in brackets next to the strain name

temperature of $10-40{ }^{\circ} \mathrm{C}, \mathrm{pH}$ of $5.0-9.0$, and salinity of 5-60 g/l [3]. The basic details of its genome sequence are shown in Table 1.

\section{Chemotaxonomic data}

The major cellular fatty acids that were present in strain 42BKT ${ }^{\mathrm{T}}$ included $\mathrm{C}_{16: 1}$ (53.7\%), $\mathrm{C}_{16: 0}(31.3 \%)$, and $\mathrm{C}_{18: 0}$ (15.0\%) [3]. It did not contain $C_{14: 0}, C_{14: 1}$, or $C_{18: 1}$, whereas S. aggregans Monchim $33^{\mathrm{T}}$ contains $7.7,5.9$, and $9.4 \%$, respectively, of these fatty acids [3, 7], and Sulfurimonas autotrophica $\mathrm{OK} 10^{\mathrm{T}}$, another chemolithoautotrophic bacteria, contains $8.4 \%$ of $\mathrm{C}_{14: 0}$ and $9.4 \%$ of $\mathrm{C}_{18: 1}$ [8]. S. lithotrophicum $42 \mathrm{BKT}^{\mathrm{T}}$ can fix $\mathrm{CO}_{2}$ via the reductive tricarboxylic acid (TCA) cycle, although the gene encoding phosphoenolpyruvate (PEP) carboxylase is not annotated in its genome. Sulfur or $\mathrm{S}_{2} \mathrm{O}_{3}^{2-}$ are oxidized by bacteria of the genus

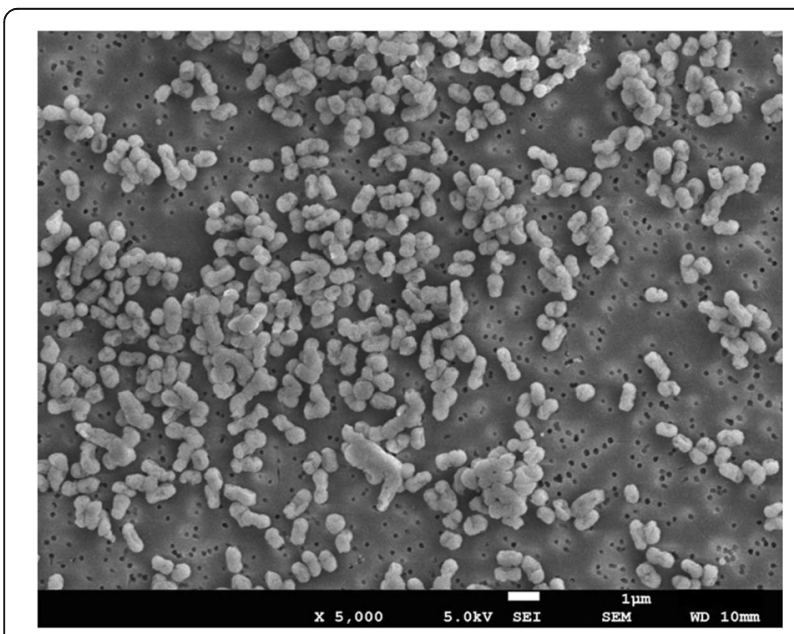

Fig. 2 Scanning electron micrograph of Sulfurovum lithotrophicum $42 \mathrm{BKT}^{\top}$
Sulfurovum; S. lithotrophicum $42 \mathrm{BKT}^{\mathrm{T}}$ can oxidize $\mathrm{S}^{2-}$ only using a sulfide-quinone reductase, whereas Sulfurovum sp. NBC37-1 oxidizes $\mathrm{S}^{2-}$ using a sulfide-quinone reductase or a sulfide dehydrogenase.

\section{Genome sequencing information}

\section{Genome project history}

S. lithotrophicum $42 \mathrm{BKT}^{\mathrm{T}}$ was selected for sequencing based on its ability to convert $\mathrm{CO}_{2}$ into $\mathrm{C}_{5} \mathrm{H}_{8} \mathrm{NO}_{4}^{-}$, which can be industrially used for $\mathrm{CO}_{2}$ bio-mitigation. The draft sequencing and annotation were performed by ChunLab, Inc. (Seoul, Korea). The genome project was deposited in the Genomes OnLine Database [9] under the accession number Gp0118364. The complete genome sequence was also deposited in GenBank [10] under the accession number CP011308. Table 2 contains the details of the project and its association with MIGS version 2.0 compliance [11].

\section{Growth conditions and genomic DNA preparation}

S. lithotrophicum $42 \mathrm{BKT}^{\mathrm{T}}$ was grown in a $125-\mathrm{mL}$ serum bottle (Wheaton Industries, Millville, NJ, USA) with $20 \mathrm{~mL}$ of $\mathrm{MJ}$ basal medium and filled with a $\mathrm{CO}_{2} /$ $\mathrm{N}_{2}$ gas mixture. The bottle was incubated at $29{ }^{\circ} \mathrm{C}$ while shaking at $120 \mathrm{rpm}$ (Green Shaker, Vision Scientific Co., Daejeon, Korea) [4]. Genomic DNA was isolated using a QIAmp DNA mini kit (Qiagen, Hilden, Germany), according to the manufacturer's instructions.

\section{Genome sequencing and assembly}

The genomic library was sequenced using an Illumina MiSeq PE 300 and PacBio $10 \mathrm{~K}$ with the Illumina 300-bp paired-end library (Illumina, San Diego, CA, USA) and the PacBio $20 \mathrm{~K}$ library (Pacific Biosciences, Menlo Park, CA, USA), respectively. The generated paired-end sequencing 
Table 1 Classification and general features of Sulfurovum lithotrophicum strain $42 \mathrm{BKT}^{\top}[11]$

\begin{tabular}{|c|c|c|c|}
\hline MIGS ID & Property & Term & $\begin{array}{l}\text { Evidence } \\
\text { code }^{a}\end{array}$ \\
\hline & Classification & Domain Bacteria & TAS [29] \\
\hline & & Phylum Proteobacteria & TAS [30] \\
\hline & & Class Epsilonproteobacteria & TAS [31] \\
\hline & & Order Campylobacterales & TAS [32] \\
\hline & & Family Helicobacteraceae & TAS [33] \\
\hline & & Genus Sulfurovum & TAS [3] \\
\hline & & $\begin{array}{l}\text { Species Sulfurovum } \\
\text { lithotrophicum }\end{array}$ & TAS [3] \\
\hline & & $\begin{array}{l}\text { Type strain: } 42 \mathrm{BKT}^{\top} \\
\text { (CP011308) }\end{array}$ & TAS [3] \\
\hline & Gram stain & Negative & TAS [3] \\
\hline & Cell shape & Coccoid to short rods & TAS [3] \\
\hline & Motility & None-motile & TAS [3] \\
\hline & Sporulation & Not reported & NAS \\
\hline & $\begin{array}{l}\text { Temperature } \\
\text { range }\end{array}$ & $10-40{ }^{\circ} \mathrm{C}$ & TAS [3] \\
\hline & $\begin{array}{l}\text { Optimum } \\
\text { temperature }\end{array}$ & $28-30^{\circ} \mathrm{C}$ & TAS [3] \\
\hline & $\begin{array}{l}\text { pH range; } \\
\text { Optimum }\end{array}$ & $6.5-7.0$ & TAS [3] \\
\hline & Carbon source & Sodium bicarbonate & TAS [4] \\
\hline MIGS-6 & Habitat & $\begin{array}{l}\text { Deep-sea hydrothermal } \\
\text { vent }\end{array}$ & TAS [3] \\
\hline MIGS-6.3 & Salinity & $0.5-6 \% \mathrm{NaCl}(w / v)$ & TAS [3] \\
\hline MIGS-22 & $\begin{array}{l}\text { Oxygen } \\
\text { requirement }\end{array}$ & Facultatively anaerobic & TAS [3] \\
\hline MIGS-15 & Biotic relationship & Symbiont & TAS [3] \\
\hline MIGS-14 & Pathogenicity & Not reported & NAS \\
\hline MIGS-4 & $\begin{array}{l}\text { Geographic } \\
\text { location }\end{array}$ & Okinawa, Japan & TAS [3] \\
\hline MIGS-5 & Sample collection & April 2002 & TAS [3] \\
\hline MIGS-4.1 & Latitude & $27^{\circ} 47.38^{\prime} \mathrm{N}$ & TAS [3] \\
\hline MIGS-4.2 & Longitude & $126^{\circ} 53.87^{\prime} \mathrm{E}$ & TAS [3] \\
\hline MIGS-4.4 & Altitude & $-1033 m$ & TAS [3] \\
\hline
\end{tabular}

a Evidence codes - TAS Traceable Author Statement (i.e., a direct report exists in the literature); NAS Non-traceable Author Statement (i.e., not directly observed for the living, isolated sample, but based on a generally accepted property for the species or anecdotal evidence). These evidence codes are from the Gene Ontology project [34]

reads (total read length: $2217,891 \mathrm{bp}$ ) were assembled using the CLC Genomics Workbench version 7.5.1 (CLC Bio, Aarhus, Denmark) and PacBio SMRT Analysis version 2.3 (Pacific Biosciences), resulting in one contig with an average genome coverage of $852.21 \times$.

\section{Genome annotation}

The genome was annotated using the NCBI Prokaryotic Genome Annotation Pipeline [12], which was designed
Table 2 Project information

\begin{tabular}{|c|c|c|}
\hline MIGS ID & Property & Term \\
\hline MIGS 31 & Finishing quality & Completely finished \\
\hline MIGS 28 & Libraries used & $\begin{array}{l}\text { Illumina 300-bp paired-end } \\
\text { library, } \\
\text { PacBio } 20 \text { K library }\end{array}$ \\
\hline MIGS 29 & Sequencing platforms & Miseq PE 300, PacBio $10 \mathrm{~K}$ \\
\hline MIGS 31.2 & Fold coverage & $852.21 \times$ \\
\hline MIGS 30 & Assemblers & $\begin{array}{l}\text { CLC Genomics Workbench v.7.5.1, } \\
\text { SMRT Analysis v.2.3 }\end{array}$ \\
\hline \multirow[t]{6}{*}{ MIGS 32} & Gene-calling method & Prodigal 2.6.2 \\
\hline & Locus Tag & YH65 \\
\hline & Genbank ID & СР011308.1 \\
\hline & $\begin{array}{l}\text { Genbank Date of } \\
\text { Release }\end{array}$ & 08/20/2015 \\
\hline & GOLD ID & Gp0118364 \\
\hline & BIOPROJECT & PRJNA279430 \\
\hline \multirow[t]{2}{*}{ MIGS 13} & Source-material identifier & $42 \mathrm{BKT}^{\top} / \mathrm{ATCC}$ BAA- $797^{\top}$ \\
\hline & Project relevance & $\mathrm{CO}_{2}$ fixation \\
\hline
\end{tabular}

to annotate bacterial genomes. Genome annotation was performed by predicting protein-coding, rRNA, tRNA, ncRNA, and pseudo genes. Phobius [13] was used to predict signal-peptide genes, and TMHMM Server version 2.0 [14] was used to predict transmembrane helix genes $[15,16]$. Protein families [17] were investigated using Pfam 29.0 [18], and GeneMarkS+ [19], which uses alignment data for gene prediction, was used as an annotation tool [20].

\section{Genome properties}

The genome of $S$. lithotrophicum $42 \mathrm{BKT}^{\mathrm{T}}$ comprised a single circular chromosome of 2217,891 bp with a GC content of $44.26 \%$. Among the 2217 genes predicted, 2146 (96.80\%) were protein-coding DNA sequences, 17 of which were pseudogenes. Among the CDSs, $89.66 \%$ were grouped into cluster of orthologous group functional categories. The genome contained a CRISPR array and 54 RNA genes, including 44 tRNAs, 9 rRNAs, and one ncRNA. The properties and statistics of the genome are summarized in Fig. 3 and Tables 3 and 4, 5.

\section{Insights from the genome sequence}

S. lithotrophicum $42 \mathrm{BKT}^{\mathrm{T}}$ is a sulfur-oxidizing bacterium that can fix $\mathrm{CO}_{2}$ through the reductive TCA cycle. Here, we focused on investigating its abilities for $\mathrm{CO}_{2}$ fixation and sulfur oxidation (sox), based on its genome sequence.

So far, six pathways have been associated with $\mathrm{CO}_{2}$ fixation: the Calvin-Benson-Bassham or reductive pentose pathway, the reductive TCA cycle or reverse citric acid cycle, the reductive acetyl CoA or WoodLjungdahl pathway, the 3-hydroxypropionate pathway 


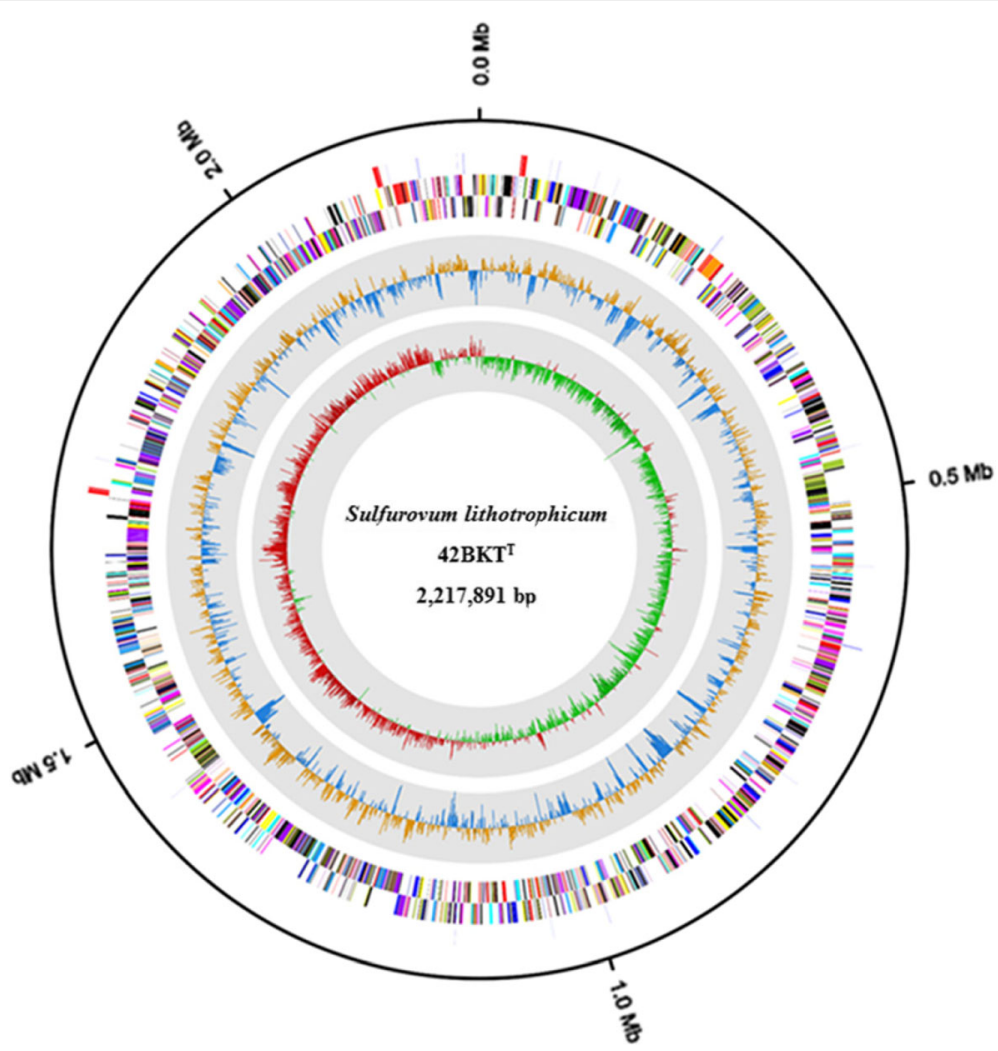

Fig. 3 Genome map of Sulfurovum lithotrophicum $42 B K T^{\top}$. From the outer to the inner circle: RNA regions (rRNA, red; tRNA, lavender), CDS on the reverse strand (colored based on COG categories), CDS on the forward strand (colored based on COG categories), G + C skew (blue/goldenrod), and GC ratio (green/red)

Table 3 Genome statistics

\begin{tabular}{lll}
\hline Attribute & Value & \% of total \\
\hline Genome size (bp) & 2217,891 & 100.00 \\
DNA coding (bp) & $2,028,222$ & 91.44 \\
DNA G + C (bp) & 981,638 & 44.26 \\
DNA scaffolds & 1 & \\
Total genes & 2217 & 100.00 \\
Protein-coding genes & 2146 & 96.80 \\
RNA genes & 54 & 2.44 \\
Pseudo genes & 17 & 0.77 \\
Genes in internal clusters & NA & NA \\
Genes with function prediction & 1559 & 70.32 \\
Genes assigned to COGs & 1979 & 89.26 \\
Genes with Pfam domains & 1770 & 79.84 \\
Genes with signal peptides & 412 & 18.58 \\
Genes with transmembrane helices & 513 & 23.14 \\
CRISPR repeats & 1 & \\
\hline
\end{tabular}

or malyl CoA pathway, the 3-hydroxypropionate/4hydroxy-butyrate cycle, and the dicarboxylate/4hydroxybutyrate cycle $[21,22]$. Similar to the majority of Epsilonproteobacteria, S. lithotrophicum $42 \mathrm{BKT}^{\mathrm{T}}$ can also grow chemoautotrophically through its adenosine triphosphate citrate lyase, 2oxoglutarate:ferredoxin oxidoreductase, and pyruvate:ferredoxin oxidoreductase via the reductive TCA cycle [23-25]. We annotated these three key enzymes, as well as other relevant enzymes such as malate dehydrogenase, fumarate hydratase, fumarate reductase, isocitrate dehydrogenase, aconitate hydratase, PEP synthase, and PEP carboxylase, in the genome sequence of $42 \mathrm{BKT}^{\mathrm{T}}$. Notably, Sulfurovum sp. NBC37-1 and Candidatus Sulfurovum sediminum AR could also assimilate $\mathrm{CO}_{2}$ via the reductive TCA cycle $[6,26]$.

S. lithotrophicum $42 \mathrm{BKT}^{\mathrm{T}}$ is known to oxidize or $\mathrm{S}_{2} \mathrm{~S}$ $\mathrm{O}_{3}^{2-}$ via a sox system using SoxB, SoxXA, SoxYZ, and Sox $(C D)_{2}$ periplasmic proteins [27]. These enzymes catalyze the oxidation of $\mathrm{S}$ or $\mathrm{S}_{2} \mathrm{O}_{3}^{2-}$ using horse cytochrome $c$ as the final electron acceptor [28]. Here, we confirmed the presence of SoxA, SoxB, SoxZ, SoxY, and SoxX genes in the $42 \mathrm{BKT}^{\mathrm{T}}$ genome. 
Table 4 Number of genes associated with the general COG functional categories

\begin{tabular}{|c|c|c|c|}
\hline Code & Value & $\%$ age $^{a}$ & Description \\
\hline J & 138 & 6.43 & Translation, ribosomal structure, and biogenesis \\
\hline A & 0 & 0.00 & RNA processing and modification \\
\hline K & 47 & 2.19 & Transcription \\
\hline L & 94 & 4.38 & Replication, recombination, and repair \\
\hline B & 1 & 0.05 & Chromatin structure and dynamics \\
\hline D & 14 & 0.65 & $\begin{array}{l}\text { Cell cycle control, cell division, chromosome } \\
\text { partitioning }\end{array}$ \\
\hline V & 18 & 0.84 & Defense mechanisms \\
\hline $\mathrm{T}$ & 88 & 4.10 & Signal-transduction mechanisms \\
\hline M & 144 & 6.71 & Cell wall/membrane/envelope biogenesis \\
\hline N & 6 & 0.28 & Cell motility \\
\hline U & 39 & 1.82 & Intracellular trafficking and secretion \\
\hline O & 95 & 4.43 & $\begin{array}{l}\text { Post-translational modification, protein turnover, } \\
\text { chaperones }\end{array}$ \\
\hline C & 138 & 6.43 & Energy production and conversion \\
\hline G & 53 & 2.47 & Carbohydrate transport and metabolism \\
\hline E & 119 & 5.55 & Amino acid transport and metabolism \\
\hline $\mathrm{F}$ & 60 & 2.80 & Nucleotide transport and metabolism \\
\hline $\mathrm{H}$ & 85 & 3.96 & Coenzyme transport and metabolism \\
\hline I & 43 & 2.00 & Lipid transport and metabolism \\
\hline$P$ & 106 & 4.94 & Inorganic ion transport and metabolism \\
\hline Q & 22 & 1.03 & $\begin{array}{l}\text { Secondary metabolites biosynthesis, transport } \\
\text { and catabolism }\end{array}$ \\
\hline $\mathrm{R}$ & 143 & 6.66 & General function prediction only \\
\hline S & 526 & 24.51 & Function unknown \\
\hline - & 238 & 11.09 & Not in COGs \\
\hline
\end{tabular}

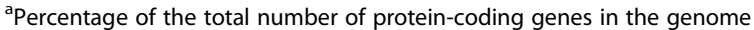

Table 5 Species in the genus Sulfurovum

\begin{tabular}{|c|c|c|c|c|c|}
\hline $\begin{array}{l}\text { Species } \\
\text { (isolation source) }\end{array}$ & $\begin{array}{l}\text { Genome } \\
\text { size }(\mathrm{Mb})\end{array}$ & Accession no. & CDS & GC (\%) & Reference \\
\hline $\begin{array}{l}\text { Sulfurovum } \\
\text { lithotrophicum } \\
42 \mathrm{BKT}^{\top} \\
\text { (Deep-sea } \\
\text { hydrothermal } \\
\text { sediment) }\end{array}$ & 2.21 & СР011308 & 2092 & 44.3 & $\begin{array}{l}\text { This } \\
\text { report }\end{array}$ \\
\hline $\begin{array}{l}\text { Sulfurovum sp. } \\
\text { NBC37-1 } \\
\text { (Deep-sea } \\
\text { hydrothermal } \\
\text { vent) }\end{array}$ & 2.56 & AP009179 & 2466 & 43.8 & [6] \\
\hline $\begin{array}{l}\text { Candidatus } \\
\text { Sulfurovum } \\
\text { sediminum AR } \\
\text { (Marine sediment) }\end{array}$ & 2.12 & AJLE01000000 & 2114 & 39.2 & [26] \\
\hline
\end{tabular}

\section{Conclusions}

To the best of our knowledge, this is the first report describing the genome sequence of $S$. lithotrophicum $42 \mathrm{BKT}^{\mathrm{T}}$, which comprised a circular chromosome of 2217,891 bp (44.26\% GC content) with 2217 genes, among which 2146 were CDSs, 17 were pseudogenes, and 54 were RNA genes. S. lithotrophicum $42 \mathrm{BKT} \mathrm{T}^{\mathrm{T}}$ assimilates $\mathrm{CO}_{2}$ via the reductive TCA cycle and oxidizes $\mathrm{S}$ or $\mathrm{S}_{2} \mathrm{O}_{3}^{2-}$ via the sox system. The details of the genome sequence of this strain could provide potential strategies to enhance the industrial application of such bacteria for $\mathrm{CO}_{2}$ bio-mitigation.

\section{Abbreviations \\ CDS: Coding DNA sequence; COG: Cluster of orthologous group: PEP: Phosphoenolpyruvate; TCA: Tricarboxylic acid \\ Funding \\ This study was supported by a grant from the KRIBB Research Initiative Program, and Industrial Strategic Technology Development Program (10067772, Development of bio-glutaric acid based plasticizers) funded by the Ministry of Trade, Industry \& Energy (MOTIE, Korea).}

\section{Authors' contributions}

WJ and GP performed the microbial cultivation and genomic DNA isolation. $\mathrm{LP}$ and $\mathrm{HL}$ performed the phylogenetic analysis. WJ, LP, and NL performed sequencing and data analysis. WJ, $\mathrm{LP}$, and JA drafted the manuscript. DL, HK, $I A, C L, H L$, and $J A$ edited the manuscript. All the authors have read and approved the final manuscript.

\section{Competing interests}

The authors declare that they have no competing interests.

\section{Publisher's Note}

Springer Nature remains neutral with regard to jurisdictional claims in published maps and institutional affiliations.

\section{Author details}

'Biotechnology Process Engineering Center, KRIBB, 40 Yeongudanji-ro, Cheongju 363-883, South Korea. ${ }^{2}$ Bioprocess Department, University of Science and Technology, 217 Gajeong-ro Yuseong-gu, Daejeon, South Korea. ${ }^{3}$ Chemical Engineering Study Program, Faculty of Industrial Technology, Institut Teknologi Bandung, Jl.Ganesa No. 10, Bandung 40132, Indonesia. ${ }^{4}$ Department of Chemical and Biomolecular Engineering, National University of Singapore, 4 Engineering Drive 4, Singapore 117576, Singapore. ${ }^{5}$ Department of Chemical and Biomolecular Engineering, Yonsei University, 50 Yonsei-ro, Seodaemun-gu, Seoul 120-749, South Korea.

Received: 2 January 2017 Accepted: 23 August 2017

Published online: 06 September 2017

\section{References}

1. Nakagawa S, Takai K, Inagaki F, Hirayama H, Nunoura T, Horikoshi K, Sako Y. Distribution, phylogenetic diversity and physiological characteristics of epsilon-Proteobacteria in a deep-sea hydrothermal field. Environ Microbiol. 2005;7:1619-32.

2. Huber JA, Butterfield DA, Baross JA. Bacterial diversity in a subseafloor habitat following a deep-sea volcanic eruption. FEMS Microbiol Ecol. 2003; 43:393-409.

3. Inagaki F, Takai K, Nealson KH, Horikoshi K. Sulfurovum lithotrophicum gen. nov., sp. nov., a novel sulfur-oxidizing chemolithoautotroph within the epsilon-Proteobacteria isolated from Okinawa trough hydrothermal sediments. Int J Syst Evol Microbiol. 2004;54:1477-82.

4. Kwon HS, Lee JH, Kim T, Kim JJ, Jeon P, Lee CH, Ahn IS. Biofixation of a high-concentration of carbon dioxide using a deep-sea bacterium: Sulfurovum lithotrophicum 42BKTT. RSC Adv. 2015:5:7151-9.

5. NCBI BLAST. https://blast.ncbi.nlm.nih.gov/Blast.cgi. Accessed 17 Jan 2017. 
6. Nakagawa S, Takaki Y, Shimamura S, Reysenbach AL, Takai K, Horikoshi K Deep-sea vent epsilon-proteobacterial genomes provide insights into emergence of pathogens. Proc Natl Acad Sci U S A. 2007;104:12146-50.

7. Mino S, Kudo H, Arai T, Sawabe T, Takai K, Nakagawa S. Sulfurovum aggregans sp. nov.,a hydrogen-oxidizing, thiosulfate-reducing chemolithoautotroph within the Epsilonproteobacteria isolated from a deepsea hydrothermal vent chimney, and an emended description of the genus Sulfurovum. Int J Syst Evol Microbiol. 2014;64:3195-201.

8. Inagaki F, Takai K, Kobayashi H, Nealson KH, Horikoshi K. Sulfurimonas autotrophica gen. nov., sp. nov., a novel sulfur-oxidizing epsilonproteobacterium isolated from hydrothermal sediments in the Mid-Okinawa Trough. Int J Syst Evol Microbiol. 2003;53:1801-5.

9. Genomes OnLine Database. https://gold.jgi.doe.gov/. Accessed 17 Jan 2017.

10. GenBank. https://www.ncbi.nlm.nih.gov/genbank/. Accessed 17 Jan 2017.

11. Field D, Garrity G, Gray T, Morrison N, Selengut J, Sterk P, Tatusova T, Thomson $\mathrm{N}$, Allen MJ. Angiuoli SV and others. The minimum information about a genome sequence (MIGS) specification. Nat Biotechnol. 2008;26:541-7.

12. NCBI Prokaryotic Genome Annotation Pipeline. https://www.ncbi.nlm.nih. gov/genome/annotation_prok/. Accessed 17 Jan 2017.

13. Phobius. http://phobius.sbc.su.se/. Accessed 17 Jan 2017.

14. TMHMM Server version 2.0. http://www.cbs.dtu.dk/services/TMHMM/. Accessed 17 Jan 2017.

15. Kall L, Krogh A, Sonnhammer EL. Advantages of combined transmembrane topology and signal peptide prediction-the Phobius web server. Nucleic Acids Res. 2007;35:W429-32.

16. Krogh A, Larsson B, von Heijne G, Sonnhammer EL. Predicting transmembrane protein topology with a hidden Markov model: application to complete genomes. J Mol Biol. 2001;305:567-80.

17. Bateman A, Birney E, Durbin R, Eddy SR, Howe KL, Sonnhammer ELL. The Pfam protein families database. Nucleic Acids Res. 2000;28:263-6.

18. Pfam 29.0. http://pfam.xfam.org/. Accessed 17 Jan 2017.

19. GeneMarkS+. http://exon.gatech.edu/Genemark/genemarks.cgi. Accessed 17 Jan 2017.

20. Besemer J, Lomsadze A, Borodovsky M. GeneMarkS: a self-training method for prediction of gene starts in microbial genomes. Implications for finding sequence motifs in regulatory regions. Nucleic Acids Res. 2001;29:2607-18.

21. Saini R, Kapoor R, Kumar R, Siddiqi TO, Kumar A. CO(2) utilizing microbes-a comprehensive review. Biotechnol Adv. 2011;29:949-60.

22. Kanao T, Fukui T, Atomi H, Imanaka T. ATP-citrate lyase from the green sulfur bacterium Chlorobium limicola is a heteromeric enzyme composed of two distinct gene products. Eur J Biochem. 2001;268:1670-8.

23. Hügler M, Gärtner A, Imhoff JF. Functional genes as markers for sulfur cycling and $\mathrm{CO} 2$ fixation in microbial communities of hydrothermal vents of the Logatchev field. FEMS Microbiol Ecol. 2010;73:526-37.

24. Hugler M, Wirsen CO, Fuchs G, Taylor CD, Sievert SM. Evidence for autotrophic $\mathrm{CO} 2$ fixation via the reductive tricarboxylic acid cycle by members of the epsilon subdivision of proteobacteria. J Bacteriol. 2005;187:3020-7.

25. Takai K, Campbell BJ, Cary SC, Suzuki M, Oida H, Nunoura T, Hirayama H, Nakagawa S, Suzuki Y, Inagaki F, et al. Enzymatic and genetic characterization of carbon and energy metabolisms by deep-sea hydrothermal chemolithoautotrophic isolates of Epsilonproteobacteria. Appl Environ Microbiol. 2005;71:7310-20.

26. Park SJ, Ghai R, Martin-Cuadrado AB, Rodriguez-Valera F, Jung MY, Kim JG, Rhee SK. Draft genome sequence of the sulfur-oxidizing bacterium "Candidatus Sulfurovum sediminum" AR, which belongs to the Epsilonproteobacteria. J Bacteriol. 2012;194:4128-9.

27. Friedrich CG, Bardischewsky F, Rother D, Quentmeier A, Fischer J. Prokaryotic sulfur oxidation. Curr Opin Microbiol. 2005;8:253-9.

28. Bardischewsky F, Quentmeier A, Rother D, Hellwig P, Kostka S, Friedrich CG. Sulfur dehydrogenase of Paracoccus pantotrophus: the heme-2 domain of the molybdoprotein cytochrome c complex is dispensable for catalytic activity. Biochemistry. 2005;44:7024-34.

29. Woese CR, Kandler O, Wheelis ML. Towards a natural system of organisms: proposal for the domains Archaea, Bacteria, and Eucarya. Proc Natl Acad Sci U S A. 1980;87:4576-9.

30. Garrity GM, Bell JA, LT. Phylum. XIV. Proteobacteria phyl. nov. Bergey's manual of systematic bacteriology 2005, 2, Part B: 1.

31. Garrity GM, Bell JA, Lilburn T. Class V. Epsilonproteobacteria class. nov. Bergey's manual of systematic bacteriology. 2005, 2, Part C: 1145.

32. Garrity GM, Bell JA, Lilburn T. Order I. Campylobacterales ord. nov. Bergey's manual of systematic bacteriology 2005, 2, Part C: 1145.
33. Garrity GM, Bell JA, Lilburn T. Family II. Helicobacteraceae fam. nov. Bergey's manual of systematic bacteriology. 2005, 2, Part C: 1168.

34. Ashburner M, Ball CA, Blake JA, Botstein D, Butler H, Cherry JM, Davis AP, Dolinski K, Dwight SS, Eppig JT, et al. Gene ontology: tool for the unification of biology. The gene ontology consortium. Nat Genet. 2000;25:25-9.

35. Saitou N, Nei M. The neighbor-joining method: a new method for reconstructing phylogenetic trees. Mol Biol Evol. 1987;4:406-25.

36. Tamura K, Nei M, Kumar S. Prospects for inferring very large phylogenies by using the neighbor-joining method. Proc Natl Acad Sci U S A. 2004;101:11030-5.

37. Felsenstein J. Confidence limits on phylogenies: an approach using the bootstrap. Evolution. 1985;39:783-91.

38. Tamura K, Stecher G, Peterson D, Filipski A, Kumar S. MEGA6: molecular evolutionary genetics analysis version 6.0. Mol Biol Evol. 2013;30:2725-9.

\section{Submit your next manuscript to BioMed Central and we will help you at every step:}

- We accept pre-submission inquiries

- Our selector tool helps you to find the most relevant journal

- We provide round the clock customer support

- Convenient online submission

- Thorough peer review

- Inclusion in PubMed and all major indexing services

- Maximum visibility for your research

Submit your manuscript at www.biomedcentral.com/submit
) Biomed Central 